Österreichische Akademie der Wissenschaften / Austrian Academy of Sciences AAS WORKING PAPERS IN SOCIAL ANTHROPOLOGY Volume 34

Frank Heidemann

THE MARINE ECONOMY AND THE SEAMEN'S ETHOS OF MINICOY (MALIKU), SOUTH WEST INDIA

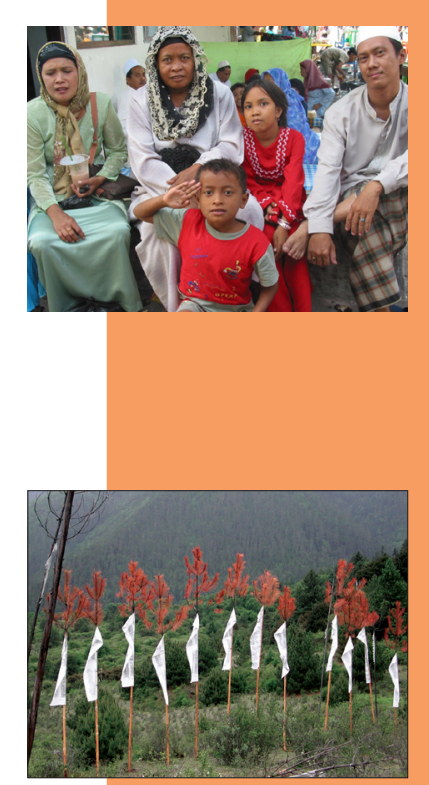




\section{AAS Working Papers in Social Anthropology / \\ ÖAW Arbeitspapiere zur Sozialanthropologie}

ISBN-Online: 978-3-7001-8395-2

DOI: $10.1553 /$ wpsa34

Wien 2019

Editors / Herausgeber:

Andre Gingrich \& Guntram Hazod

(C) Institut für Sozialanthropologie

Österreichische Akademie der Wissenschaften

Hollandstraße 11-13

A-1020 Wien

Fax: 01/ 51581-6450

E-Mail: sozialanthropologie@oeaw.ac.at 


\title{
THE MARINE ECONOMY AND THE SEAMEN'S ETHOS OF MINICOY (MALIKU), SOUTH WEST INDIA ${ }^{1}$
}

\author{
FRANK HEIDEMANN
}

\section{An island "in-between"}

Minicoy, locally called "Maliku", is the southernmost island of Lakshadweep, an Indian Union Territory, app. $400 \mathrm{~km}$ west of South India, in between the eight and nine degree channel, and old shipping routes from west to east. It is located app. $200 \mathrm{~km}$ south of Kalpeni, the nearest island of the U.T. of Lakshadweep, and app. $125 \mathrm{~km}$ north of the nearest atoll of the Maldives. The crescent shaped island, about $10 \mathrm{~km}$ long and with a maximal width of less than one kilometre, is the home of 10,444 people (Census of India 2011). Once, it was the northernmost part of the Sultanate of the Maldives, but it became a tributary of the South Indian Ali Rajas some time around $1500 \mathrm{AD}$ and has been part of the Indian Union since 1956. It is an island "inbetween". The people of Maliku speak Mahal, a dialect of Divehi, the national language of the Maldives, and have kinship-relations to "the south". Their political affiliation and all economic links are to "the north", to the Laccadive and Amindivi islands and to India. Their religion, Islam, came (via the Maldives' capital Male') from "the west". All people of Maliku follow the Sunni way of Islamic faith and have a matrilineal kinship system and matrilocal residence. The Indian state classified them as "scheduled tribes", an administrative category with a fixed quota for educational institutions and government jobs. In short: Maliku occupies a special place in the cultural landscape, in history and in the plurality of Indian social systems.

This text is based on historical accounts ${ }^{2}$ and academic writings, ${ }^{3}$ but it emerged after I met people from Maliku and learned about their present life. I shall make a historical argument from an anthropological perspective. At the time of early functionalism there has been a divide of historical and anthropological sciences. Bronislaw Malinowski's (1922) view on remote island communities was largely ahistorical and instrumental for the formation of a new discipline of the cultural other. But the work of Eric Wolf (2010), Johannes Fabian (1983) and others demonstrate the deep connectivity of the past and the present, the local and the global. The school of subaltern studies emerged from a re-reading of South Asian history and paved the way for the

\footnotetext{
${ }^{1}$ I like to thank Andre Gingrich, Ellen Kattner, Mohammed Kolugege, Eva-Maria Knoll and Burkhard Schnepel for comments on the first draft of this text. This working paper is based on the International Guest Lecture "Living by the sea: The political history and marine economy of Minicoy (South Lakshadweep)" held in October 2018 at the Institute for Social Anthropology, Austrian Academy of Sciences.

${ }^{2}$ Several sources quoted here are from a compilation of historical texts, edited by Lars Vilgon in 9 volumes (1991-1999). Vilgon was a retired captain, who collected documents from Libraries around the world and published the translation in his "Maldive Odd History". He deposited copies in several libraries in the USA, Europe and in Male'.

${ }^{3}$ Most academic writings on the Maldives, including the comprehensive books of Clarence Maloney (1980) and Xavier Romero-Frias (2003), mention Minicoy, but cannot draw on empirical data of their own. Most anthropological research on the Lakshadweep excludes Minicoy, except the publications of Ellen Kattner, who stayed on the island for one year in 1990/91. For sources on the history of the Laccadive Islands see Forbes (1979).
} 
inter-disciplinary project of postcolonial studies. Bernhard Cohn's "As an anthropologist among historians" (1987) became a classic and his student Nicholas Dirks formulated the concept of the colonial "ethnographic state" (2001). The following discussion of the history of Maliku is written on the backdrop of these works and tries to rethink history from an anthropologist's point of view.

My point of departure is the work of Burkhard Schnepel and Edward Alpers on small islands in history. Alpers investigated "the integral role that these islands have played and continue to play over several millennia in the history of the Indian Ocean" (quoted in Schnepel 2018: 5). In this line, Schnepel argues that "insularity is not detrimental to globality, but integral to it" (ibid.: 24). He rejects the continental view and takes islands in their own rights. The focus on islands as hubs and their potential for connectivity are central in this volume. There is no doubt that small islands became indispensable links in trade and rule in the ocean world and were used as stepping stones before and during colonialism. The volume "Connectivity in Motion" (Schnepel and Alpers 2018) offers a new view on the island world and Maliku can be seen as a sounding board of this thesis. The location of this island is on the main sailing route from Sri Lanka to Oman and Yemen and we have several records of ships stopping there. In addition, this island was the last stopover from the Sultanate of the Maldives for ships heading to South India. In the words of Ellen Kattner (2003), Maliku functioned as caravanserai in the Indian Ocean. No doubt, Maliku had the qualities of a small hub.

\section{Hub, home and headquarters}

When I spoke to seamen from Maliku in Kaloor, an urban quarter in Kochi (former Cochin) the concept of a hub did not appear in their narratives. ${ }^{4}$ Like most of the men from this island they learned how to fish and how to sail in their teenage years and became seamen in their early twenties. In their life-histories their home island appears as a place of origin and of longing. It is an anchor in their life. They remember their childhood and await their retirement in their native village. One sailor described the movement of his fellows like the work of the bees, who go out for work and come back to their origin. The eldest among my interlocutors remembered the annual return of the trading boats, bringing rice and rare fruits. Others remember ships of unknown origin, which lost their way and stranded there. But there was no word of a regular visitor passing this island. The small island is pictured as a place, where tuna is processed and coconut commodities are produced for export. The island appears not as a hub, but as a home and as a centre; as a place, where commodities were produced and ships repaired. After a brief introduction I will argue for Maliku as a-home-cum-headquarters in more detail further down.

The semantic field of "hub" includes airports and harbours where the main function is to connect people or to re-load merchandise. Hubs are created for logistic services and the importance of a hub is described in the annual turnover of passengers and goods. In contrast, a home is the centre of one's life, and the origin of sociality, social values, and of embodied knowledge. A headquarters is a productive or creative centre, where goods are produced and coordination

\footnotetext{
${ }^{4}$ In March 2018 I spoke to more than ten seamen from Maliku in Kaloor, a central quarter of Kochi town. Most statements, which are quoted below, came from more than one individual. To ensure their anonymity, I shall quote them as "Maliku seamen from Kaloor".
} 
takes place. A police-headquarters, a district headquarters of a capital of a nation state, and a principle office of a company are classical examples of this category. A headquarters attracts people or raw material, transforms matter and mind, and disperses whatever is transformed. Looking at the historical records of Maliku, the island functioned as a mine for cowry shells, as a production unit for dried fish and coir ropes, as a ship-building place, and as the home of seafarers, pilots, captains and traders, as a hideaway for politically refugees, as an anchor place for ships in trouble, as a destination for Islamic preachers etc. In sum, the model of a small homecum-headquarters appears more appropriate than that of a hub.

The idea of Maliku as a centre for marine technology and shipbuilding can be found in-between the lines of Timothy Severin's book The Sindbad Voyage (1982). It describes a voyage with a reconstruction of a traditional Arab sailing ship (a boom - probably better known by the generic term dhow) from Oman to China. The book begins with the search for materials and craftsmen for the construction of the ship. He employed Muraiduganduar Ali Manikfan, ${ }^{5}$ (the son of the last selected island headman) from Maliku, who was said to speak 14 languages, and who had his own personal networks on the Lakshadweep Islands and on the Indian mainland. In the beginning Ali Manikfan worked as an interpreter but soon he became a crucial organiser for the endeavour. He was instrumental in getting the coir ropes for the construction of the Sohar made on the Laccadive Islands. The husks of the coconut shells, after retting in sea water, they "must be dried in the sun, then pounded with wooden clubs on wood blocks to loosen the powder. If a metal hammer were used for pounding, the fibres would be crushed and damaged ..." (Severin 1982: 40). The Laccadive islands are known as coir islands and were under the coir monopoly during the rule of the British. The ropes produced there have been renowned for their quality since time immemorial. Following Ali Manikfan's advice the sails were produced by skilled craftsmen on the Kerala coast and expert ship-builders from Maliku were engaged to supervise the construction in Oman and form part of the later crew. Until today, ship-building is called "ship sewing" in Maliku (ibid.: 38ff.). Severin describes the men of Maliku as "the best seamen of India" (ibid.: 39). ${ }^{6}$ They are raised on the small island, where "(e)very man is expected to be able to look after himself, to fish and to tend the coconut trees built his own house, cook and swim, and work as a member of a team" (Severin 1982: 39). ${ }^{7}$ People from Maliku, Severin says, "were the original Lascars who, for generations, have signed on as deck hands with foreign ships." (ibid.) The team of the Bombay Pilot Services is staffed by men from Maliku exclusively, "and whatever happens, in foul weather or emergency the Minicoy men keep their boats on station. Moreover, ... in Bombay's labour-troubled port the Minicoy men never go on strike" (ibid.: 39-40).

\footnotetext{
${ }^{5}$ About the life-history of Ali Manikfan see Romero-Frias (n.d.).

${ }^{6}$ W. Logan, who visited Maliku about one hundred years before Severin built the Sohar, observed: The "smart Minicovite ... are born seamen, as we shall presently learn." The native boats are "(i)sland built, island rigged, and named after smar island-seamen, familiar with the use of the sixtant and European navigation tables, these boats set out on trading voyages annually, to the Maldives, to the Malabar coast, and Colombo, and farther still, to the Bay of Bengal" (Logan 1889, in: Vilgon, vol. 2: 113). "The men are excellent sailors; their fishing boats, which are the best which I have ever seen on any of the Indian coasts, are very fast, though the sails are almost entirely of coco-palm mattings" (Basevi 1872: 371).

${ }^{7}$ It has to be added that "climbing coconut trees" was the task of the raverin, one of the local status groups, who worked on the island and not on boats.
} 
The specialisation on maritime affairs does not come as a surprise. The first settlers must have come by boats and after the settlement boats were the nucleus of all infrastructure. They were used for fishing, for transport and for trade. We do not know when and how the maritime economy in Maliku emerged, but in 1515 Duarte Barbosa, a Portuguese official, wrote that the "Malabar Moors" say, that Maliku "belong to the King of Cannanor" (Barbosa 1515, in: Vilgon, vol. 7: 11). In Maliku "they build many great ships of palm trunks, sewn together with thread, for they have no other timber, and in these they sail to the main (land) - they have great store of dried fish, they have "Buziros" (Cowries), (...) ambergris is found in large lumps" (ibid.: 13). The specialisation of skills and crafts is also reflected in the order of the four (formerly) endogamous groups. Boduy own private land and ships, niamin act as captains, medukembiy constitute the crew and raveriy work on land, harvest the coconut and make the coir products (Kattner 1996: 20). These groups constitute a hierarchy, which is known until today, but the exclusive use of privileges like wearing sandals versus walking barefoot etc. is a matter of the past (Kulikov 2014).

Today, male members of all four status-groups work on ships. All were raised with (what I would call) a seaman's ethos. The ocean is considered as the space of men, of hard work, of economic success and a place of longing. From childhood they know that "men have to be out most of the time" (Maliku seamen in Kaloor 2018). On ships they respect hierarchies, which are not based on birth or hereditary status groups, but ensure quick decisions and immediate action. Seamen seek social mobility in form of promotion, and most of them climbed up in the functional order. Social hierarchy among seamen is based on experience, years of service, rank in the ship's hierarchy, income, and places they have seen. They are proud of their collective fame as perfect seamen and it is a matter of pride to maintain this reputation. By way of making a difference to seamen from the mainland, an elderly interlocutor said: "In India, for each trade you have a separate caste, but in Maliku everyone knows each craft. Each man can build his house and knows carpentry, bricklaying, plumbing and wiring." (Maliku seamen in Kaloor 2018) The social system in Maliku was made for both the production of goods for a local market and to sail the oceans. And so are her people.

In the following I shall argue that Maliku was a small but effective centre of creativity. I shall ask about the contribution by this (and potential other) little island to the pre-colonial and colonial history of the Indian Ocean. First, I shall consider the unique marine economy of the island and then the political practice of the external rule over Maliku. I shall argue that the topography, the economy and the political practice contributed to a specific seamen's ethos and that this ethos endured major societal changes. Ethos is - like embodiment - an "indeterminate methodological field" (Csordas 2011: 138). Foucault, Bourdieu and Merleau-Ponty offer different models how the body and the world are interrelated. Embodied experiences contribute to the shape of ideas and values and cannot be diverted from social norms and ethos. My use of the term ethos follows the short definition of the Cambridge English dictionary "the set of ideas, beliefs, etc. about the social behaviour and relationships of a person or group". ${ }^{8}$ I consider ethos

\footnotetext{
${ }^{8}$ https://dictionary.cambridge.org/dictionary/english/ethos, download on Dec. 14, 2018.
} 
as the ethical dimension of a habitus, which is according to Pierre Bourdieu (1990: 52ff.) a much more complex totality of dispositions, attitudes and performance. ${ }^{9}$

\section{A marine economy}

The people of Maliku live by the sea. The ocean is a steady factor in their history and their identity. But the production and import of commodities, trade, mobility and ways of earning a living was also dependent on political rule, external forces, tributary systems and colonialism. Before the Maldives, and therefore Minicoy, converted to Islam in 1153 (Knoll 2018), Buddhism was the main religion. There are hardly any historical records of this time and we know of no restrictions in maritime mobility and economic production (Kattner 2010). For several centuries Maliku was a part of the Maldives, but eventually it became part of the realm of the Ali Rajas of Cannanore, a south Indian kingdom, and later under British rule. ${ }^{10}$ There are various narratives, why Maliku became part of the Indian Union.

Talking to Malikuns I came across various narratives explaining their geopolitical history. Most interlocutors confirm that Maliku was once a part of the Maldives, then a tributary to the Ali Raja and after the "defeat of Tippu Sultan" a part of British India. All attempts to ask for details lead to what my interview partner classified as rumours. Most narratives can be reduced to the following schema. The Ali Rajas took control of all Maldive islands and when they lost their power they kept Maliku because a) it had an important geopolitical position to control the Indian Ocean, b) it had fertile land and a good coir produce, c) it was a deal to keep one part and Maliku was the nearest island to the Indian coast. Xavier Romero-Frias recorded a narrative in the Maldives about the same process from Magieduruge Ibrahim Didi: In 1734 Maliku was devastated by a cyclone and did not get any support from the Sultan of the Maldives. He suggested to approach the king of Cannanore, who finally financed the rebuilding of the island. "Thereafter the Minicoy people owed allegiance to this kingdom of SW India shore. Naturally, following the Independence of India, Minicoy people became citizens of the Indian Union" (Romero-Frias 2003: 26, fn. 8).

The oldest reliable description of Maliku is from a stopover in 1607. The French sailor Francois Pyrard de Laval was shipwrecked at the Maldives and kept there in custody for more than five years. He learned the language, became an informant to the Sultan about European customs, technologies and navigation. Pyrard had access to all walks of life, including the king's court, became friend to administrators, traders and captains. He proved to be an excellent observer and after his return to France, he wrote - in collaboration with a leading French intellectual, the lawyer Hironymous Bignon - a book based on his memory (Beckmann 1809: 115-144). The

\footnotetext{
${ }^{9}$ I prefer to use the term ethos (and not habitus), because I had no access to the daily life and social practices of the seamen.

10 "Minicoy known then as Maikatholhu, was part of the Maldives until the early 16th century. The exact date when Minicoy changed hands and came under the Cannanore rule is not known, but written records indicate that the mid-17th century the islands were under the control of the Ali Raja of Cannanore" (Mohamed 2008: 19). J.P. Basevi visited the island in the 1870 and records what was told to him: The people of Minicoy "are now, and have been for the last 200 years, under the Raja of Cannanore, having voluntarily placed themselves under his rule to obtain protection against the Malabar pirates who used to molest them" (Basevi 1872: 370). For the Portuguese period of the Maldives see Villiers (1992) and for the Ali Rajas of Cannanore see Kurup (1970).
} 
editors of his translations, including Gray and Bell, consider his account as trustworthy. At the end of his stay in the Maldives, Pyrard reached Maliku after a three days sail from Oustime. This is his account.

The island is surrounded with very dangerous banks, which have to be carefully watched. Three of our galiots that had kept together cast anchor there; the other had separated. This island of Malicut is only four leagues in circumference; it is wonderfully fertile in cocotrees, bananas, millet, and other products of the Maldives; all sorts of fruit are abundant. The fishery is very good; the climate more healthy and temperate than at the Maldives; the people have the same customs, manners, and language as those of the Maldives. This island was at one time part of the Maldive realm; but a king gave it to his brother as a portion. It is now governed by a lady, who holds it of the king of Cananor, for the sake of greater security. This queen gave me a very good reception, for she had often seen me at the court of the king of the Maldives, her near relative (Pyrard 2010: 323).

In a footnote to this sections, the editors of the 1888 English translation, Gray and Bell, state that the majority of the men follow a seafaring life, trade with the Maldives, and own six big ships for the Bengal trade, four coastal vessels and eight fishing boats (ibid.). In 1885, the medical officer stationed in Maliku, Oliver Bartholomeusz adds a further note on the engagement in seafaring: The vessels "carry a large number of islanders as passengers to the chief ports of India and Ceylon, where they seek employment in steamers and other vessels as lascars" (Bartholomeusz 1885, in: Vilgon, vol. 3: 26).

The economy on Maliku was centred on maritime issues. The main economic activities were the maintenance of the coconut plantation (only raveriy were coconut-climbers), the production of coir and coir products (mostly female workers), copra, fishing and the processing of dried fish for maritime consumption, ship-building and the operation of six large ships (estimated a crew of 30-40 men), four coastal vessel (estimated 15 crew members), and eight fishing boats (with a crew of 8 to 12 men) and in addition "a large number of islanders" working on steamers and other vessels (ibid.). A look at the first census in 1881, counting 3915 persons, reveals the central importance of sailing and fishing. A rough estimate suggests that half of the population were male and out of them half the number were children, aged persons or unfit for work, therefore about one thousand to one thousand two hundred men were at work, among whom the overwhelming majority was engaged in maritime activities. While Bartholomeusz was on Minicoy, W. Logan, the Indian Government's Collector for the Malabar District visited Minicoy several times in 1889 and 1990. His graphic account has a focus on the matrilineal organisation $^{11}$ of the "Minicovites", and, in his words "born seamen, these Minicoy islanders" (Logan 1889, in: Vilgon, vol. 2: 113).

The boats are "(i)sland built, island-rigged, and named after smart island-seamen, familiar with the sextant and European navigation tables, these boats set out on trading voyages annually to the Maldives, to the Malabar coast, and Colombo, and farther still, to the Bay of Bengal. ... Chittagon is perhaps the farthest point eastward on the coast of India, Bombay the farthest point west. The annual setting out of the fleet, after the S.W.-monsoon has moderated its squally force, and its annually return in March or April, are the two events in islands life" (ibid.: 113-

${ }^{11}$ For an analysis of matrilineal organisation in the Laccadive Islands see Forbes (1978). 
15). "The islanders have been on the watch, and ... we can see boat after boat hoist their huge square lug-sails, and come away from their bait grounds inside the lagoon, under a spanking north-easterly breeze. They are all making for that narrow passage through the barrier-reef marked by a line of bacons, and handsome they look, as one by one, with curving lines and fullbreasted, with shoot through the narrow passage into the open sea ..." (ibid.: 117-19).

If we consider that the islanders of Maliku have been dependent on fishing and on imported goods right from the beginning of the settlement, that most of the male working population were included in maritime tasks, it does not come as a surprise that in the course of centuries an enormous amount of knowledge in shipbuilding, navigation, sailing and trade could be accumulated. ${ }^{12}$ From what I learn from the Maliku seamen in Kaloor, the ocean was not an antipole to the land, home and soil, but a part of their living- and working space. The lagoon appears like a bait-fish garden and a place for amusement and sport, ${ }^{13}$ the waters near to the island with ample schools of tuna are harvested like agricultural fields and the ocean served as a trading highway connecting with far away places.

We have no exact data and not even an informed guess when the men of Maliku began to work as lascars on trading ships. A rare document about those seamen is the Journal of Doctor Casper Leydon (Leydon 1805, in: Vilgon, vol. 3). In 1805 he sailed from Madras to Penang on board of the Brigg Louisa Valli, staffed by a crew from Maliku. He established personal contacts with the Malikuns by carrying out extensive interviews, and he integrated what he heard in his handwritten journal. Leydon noted down details about agriculture and animal husbandry, kinds of fish and fisheries, Muslim faith and fear of magic, the language and the alphabet. $\mathrm{He}$ made a list of 300 Mahal words and was told that the population of the island amounted to about five thousand. About the political situation he learned what historian would confirm later: Maliku was a tributary of the South Indian Ali Raja. In his words, he was told about the island "that it was taken from the Sultan of the Maldives by Adi Rajah (sic!) ... and it remained under the Bibi's authority" (...). "(T)he Raja keeps up a military force of two or three thousand men, arranged in uniform and armed with musquets, swords and spears. The force is employed in collecting his revenue from different islands." (ibid.: 69). But the seamen considered Male' as their capital and proved to be well informed about the Maldives, the geography of the islands and the procedures at the court of the Sultan. Leydon's account is the only statement of islanders about the sea army of Malabar and demonstrates that the range of seamen extended the range of Minicoy's trading boats in 1803. More than one hundred years later, W.H.R. Ellis reports that men who work on ships are away from the island for two or three years at a time (Ellis 1924: 78).

\footnotetext{
12 "Maliku is an island famous for its seafaring and shipbuilding traditions as well as for the excellence of the nautical skills of the seafaring men" (Kattner 2007: 148). Kattner argues, that the absence of men from the island contributed to the label "island of women", a description, which is proudly repeated by the people of Maliku themselves (ibid.). "In 1876 Winter Bothom visited this island and wrote that most of the people of this island worked as sailors. At that time he counted and found that there were 1179 females against 351 males (1876)" (Misra and Tiwari 1981: 233-34).

${ }^{13}$ Each of the ten villages on Maliku owns a race boat, to be rowed by men. Competition takes place annually in the lagoon, a highlight of the National Minicoy Festival (see: Times of India, 27.11.2016 https://timesofindia.indiatimes.com/city/kochi/National-Minicoy-Festival-

begins/articleshow/56208735.cms, downloaded on December 14, 2018).
} 


\section{Colonial control and local leadership}

At the time of John Casper Leydon's travel, in 1799, the British forces defeated Tippu Sultan and gained control over several territories in South India. Maliku also came under British rule, but it was leased to the Ali Rajas, therefore the revenue continued to be collected by the South Indian rulers. In the course of the nineteenth century, the power of the Cannanore Ruler shrank drastically. In 1825 a crew of Malikuns mutinied on a Malabar ship and rejected the authority of the Raja's representation on the island (Thomas 1858, in: Vilgon, vol. 7: 83). In 1850, another mutiny took place, and the Ali Raja sent a punitive expedition to the island. From the late 1850s onwards the British magisterial jurisdiction began to function, but the islanders continued to express their own rights. The islanders acted in accordance with the rule of law unless they consider that others introduced new regulations against their customary law. Listening to narratives about conflicts from the island and reading historical records reminds of a mutiny on a ship. In a way the physical boundaries of the island did not allow a rebellious fraction to withdraw or to walk away. Disputes boiled up and led to new formations of power.

In the 1880s the British presence on the island increased, and more interactions of the coloniser and the colonised took place. The lighthouse was built, masons from Ceylon were hired, and local men were engaged as labourers. Other fields of contact proved to be more complicated. In his "Short Account of the Laccadive Islands and Minicoy"14 W.H.R. Ellis (1924: 26-28) gives details about the interactions of British representatives and local people of Maliku. He offers an outsider's view based on documents from colonial offices. A graphic account describes the visit of Mr. Dance in 1884, who had visited Minicoy "to appoint a successor as Amin to the famous Dom Ali Malikhan, the richest man in Minicoy, who with his little fleet monopolised Minicoy trade, and who is still remembered throughout the Laccadives as the 'Capithan'. The people's choice rested upon Bodugothi Ali Manikfan in preference to Dom Alikhan's Brother" (ibid.). The mission to appoint the candidate and to introduce a new tax system failed. On the next trip in $1887 \mathrm{Mr}$. Logan, collector of the Malabar district, accompanied Mr. Dance, but things turned more complex. Mr. Dance found no helpers to conduct a survey, because the scheme was considered as "contrary to custom". Finally Mr. Dance informed the headman that he "would be imprisoned for obstructing the officers of the Government". "In the evening, a large noisy crowd came to the cutchery with a petition, demanding the dismissal of the Amin." ... "Later ... Mr. Dance received information that the islanders proposed to detain him on the island until he dismissed the Amin. As he had no sufficient force with him to repel them in the event of an attack or to enforce his authority, he withdrew to the steamer under the cover of night, taking with him only the Government records and maps, and of necessary leaving behind his own personal property and the Government treasure box, which was in the Amin's house in the village and could not secured in time." At the next day he sailed to Cochin and returned with " 100 men of the Special Force, to restore order." ... "So ended the affair, but the question of introducing ... a tree tax for the poll tax and tax on fishing boats, was indefinitely postponed" (all quotes in this paragraph ibid.).

Similar conflicts arose before and after the time of Mr. Dance. In 1912 Mr. Doig was the inspecting officer, and again he "was faced with a similar situation. He found the whole island

${ }^{14}$ Laccadive Islands came under the administration of Bombay Presidency, and Minicoy under the Madras Presidency. 
clamouring for the removal of an unpopular Amin. He was even threatened with detention on the island until he should dismiss the Amin, and thought it wisest to get away from the island as quietly as possible and secure police assistance from Calicut" (ibid.: 28-29). British officials never got things straight about the reasons for the unpopularity of the amin, but their suspicion was that it was all about tax collection, a demand by the British and an object of rejection by the local population. Later reports from inspecting officers could build on the knowledge gathered by their predecessor.

In 1943 J. C. Griffith visited the island and found more discontent and tension than in the previous years. He acknowledges the suspicions of the former reports, that the main reason for the tension were disputes about the South Pandaram, i.e. the southern part of the island with the coconut plantations. The Government intended to divide the common land and collected taxes individually, while the islanders managed the land on a kind of co-operative, "and the profits were divided among the people according to their custom" with the result, that nobody is "reduced to begging dole of the Inspecting Officer" (Griffith 1943, in: Vilgon, vol. 5: 41). The islanders vehemently opposed any change in this established system and opposed the Government headman, who had limited power. "As many Inspecting Officer have remarked, the influence of the officer does not long survive his departure and further schism will occur" (ibid.: 241ff.). The schism, Griffith refers to, is the opposition of the Government officer in charge of collecting taxes and the headman selected from the islanders. According to his report, Griffith could solve some of the conflicts, which smouldered on the island for years. Besides the conflict about the ownership and management of the Pandaram land, Griffith analysed further longstanding fields of conflict. One of the disputes was about the teaching of Moulvi Hussain Didi, who came from the Maldives and opposed drumming as a kind of un-Islamic pleasure. One clash was about the accounts of the Abdul Qadir Hamid Bux, a large sailing vessel, which was finally found sunk in the lagoon with six holes drilled into her.

Ali Manikfan (the son of the last selected headman, who assisted Tim Severin) was born at the time of trouble described by Griffith. He recalls the story told by his parents, that he was saved from the burning parental house when he was a baby. His own memory includes visits at the newly installed wireless stations and that emergency notes were sent to the mainland after new trouble had started. After 1956, when Maliku joined the Indian Union, "the island's international trade was classified as "smuggling", as an illegal act to be persecuted. This, in turn, the islanders could not comprehend, as for them it was unthinkable to stop economic activities they had engaged for centuries, if not millennia. The outbreak of turmoil that followed was transitory, mainly since any kind of violence, violent behaviour, and physical aggression are strongly stigmatised by the Malikun" (Kattner 2010: 165).

The same impression can be drawn from the narrative of Rodolphe Festetics de Tolna, a Hungarian nobleman, who had been sailing for seven years on the "Tolna" around the world. He was on his way from Ceylon to Yemen when he noticed a leak in his water-tank. Finally his yacht ran on a reef and de Tolna set it on fire, resulting in his involuntary stay on the island. He mentioned a "the 'HEADMAN', appointed by the English authorities, a native from Malabar coast, ...(who) was responsible for law and order, lacks all arms and forces, and lives with the islanders, he is entirely dependent of the goodwill of these" (Festetics de Tolna 1904, in: Vilgon, vol. 4: 155). His description of his time appears rather obscure, but it seems likely true 
what he mentioned about an official visitor from Male ${ }^{15}$ and his correspondence with the British administration. On February 15, 1900, he wrote to the English Collector of Malabar "to execute his power in order to help me against the natives." In his response, dated on March 8, G.W. Dance Esq., Collector of Malabar replied that he "had given the islanders order to hand you their assistance, but they are of a stiff necked people and do not obey as long as their superior not is present and can use his armed forces" (ibid.: 163). De Tolna describes his involuntary stay on Maliku as an ordeal, because he lost the loyalty of his crew and could not adapt to the customs of the island. Finally he moved away from the village with his cook, his dog, his monkey and his parrot. From the lighthouse he sent messages to passing steamers to take him and his cargo to Europe - at first without much success. Finally a ship stopped and took him home (ibid.: 189).

In sum, there has been very little control of external rulers on the daily affairs of Malikun life. The reports of the visiting inspectors depict a conflict-ridden image of the island society, because their arrival disturbed the power balance of village headman and government headman. Griffith acknowledged that Maliku formerly was an "orderly prosperous pleasant island", which was troubled by external influences. In retrospect, the islanders were open to those technologies and ideas from abroad, which they found useful, but vehemently opposed all aspects that were against their fundamental values. No doubt, the islanders defended their independence and acted strategically wise and in culturally self-determined ways.

\section{The seamen's ethos}

I would argue that the writing of Maliku's past should include relevant voices by people from the present. A first glance on the two academic fields of anthropology and history obviously will suggest that the focus of the first is on the present while the second concentrates on the past. But a more detailed examination cannot confirm this dichotomy, since history is to some extent always made in the present. What people make about the past is, in part, a construct of contemporaries. And most fields in anthropology - like identity, belonging, place-making, and ontological assumptions about the world - are rooted in a concept of the past. Conceptions of the present and of the past thus are interrelated and may in fact be seen as two sides of the same coin.

When I talked to the seamen from the island in Kaloor I did not come across the word colonialism. They talked about Ali Raja's time and annual tributes, about the British period with new taxes, unjust land-rights and the construction of the lighthouse, and about the disjunction from the Maldives after the Independence of India, but in their narratives they were (maritime) agents and not (colonial) subjects. My reading of the historical sources was and is influenced by this view. In making this statement I cannot see any methodological flaw, because each reading is biased, and any assumption of absolute academic objectivity and neutrality is a kind of daydream, if not self-deception. At the same time, my reading of Maliku's history is an attempt to consider all available sources with equal weight, being self-reflective and offering transparent

\footnotetext{
${ }^{15}$ While Festetics de Tolna stayed on the island, a member of the royal family from Male came for a visit. "The Third Vizir" to the Maldive Sultan, Velan Manikiu Maligey Hassan Didi Manikofann, arrived with his entourage and became a friend of the stranded nobleman. In Festetics de Tolna's words: "He was rich and popular to the island, where he periodically would come to buy some Toddy" (ibid.: 173).
} 
conclusions. Finally, I do not hesitate to say, that the texts of Francois Pyrard, John Leydon, Festetics de Tolna and the colonial sources from O. Bartholomeusz, W. Logan, and J.S. Griffith picture a social reality which must be read as outsiders' views on the same totality, which is implicit in the life histories of contemporary seamen.

Taking all aspects into account, Maliku can be considered a hub (Schnepel 2018) and as a caravanserai (Kattner 2003) in the sea, connecting the Arabian peninsular with Ceylon and South East Asia. But more important to my home-cum-headquarters argument, it was an island where trading boats were constructed with local materials, i.e. coconut planks were fixed with coir ropes, and marine technologies like navigation were improved. For several hundred years the daily life of a few thousand people was all about the ocean, about sailing and fishing. Tuna was cooked, dried and smoked and sold to seamen on international routes, and Maliku seamen sailed up to what is today Bangladesh, or they worked on ships commuting between Africa and China. In between their voyages, the seamen lived with their families. Their narratives and experience contributed to an ethos of seafaring. The description of Bartholomeusz from the 1880s echoes the memories of the Maliku seamen in Kaloor from 2018:

Almost all the toys used by the children are model of boats, many of which are elaborately carved and painted. It is interesting to watch the little ones swimming after their boats, as they float away with their diminutive sails filled with the wind. The children take to the water like amphibious animals, and they learn to swim as soon as they can walk and run (Bartholomeusz 1885, in: Vilgon, vol. 3: 163).

The seamen in Kaloor told me about a small board as a swimming aid and I asked them to draw it for me. Later I read the same detailed description from Bartholomeusz: "In learning to swim they use a float on which to buoy themselves. This float is a piece of light wood, about two feet long and six inches thick, flat on the upper surface, and shaped under like the bottom of a boat. With this placed lengthwise under their chest and belly, the little ones float fearless on the water, and propel themselves with their arms and legs" (ibid.). Bartholomeusz's observations suggest that fun and play becomes an embodied experience with the physical multi-sensual touch of saltwater and the ability to move in the lagoon. He did not speak Mahal and could not understand the children songs. Kaloor seamen told me that the most exciting days in their childhood were the arrival of ships. They knew songs to announce the advent of a ship, and had verses for the first sight, the entering into the lagoon, the fall of the sail, and to set the anchor.

I would argue that the contribution of Maliku - and other small islands - for the history of the Indian Ocean was more than serving as a hub, but the production of ships, and of a seamen's ethos. By seamen's ethos I mean the embodied and undisputed spirit of sailing, the ocean as a space for men, for masculine work, as a place to be and the connotation of salt water as both, danger and desire. This ethos inspired boat building, the enhancement of marine skills and the socialisation of what Severin called "the best seamen of India" (Severin 1982: 39). In addition, I would suggest that the practice of the political order of the island was influenced by the hierarchical practice on sailing boats. From the narratives of Kaloor seamen, I understand that shipcrews accept functional hierarchies. Acting on order does not violate a self-perception of an independent and self-respected individual. An individual is part of the whole, but when the whole is questioned, and a group of people rejects the leadership, revolting takes place. The descriptions by Leydon and by Logan cited above correspond to this perception: The payment 
of annual tributes to the Ali Rajas and of taxes to the British administration did not create a feeling of total submission, but were part of life with self-determination in local affairs and freedom to sail and to trade. Over a period of at least half a millennium Malikuns developed a seamen's ethos and marine technologies, both indispensable components of the first centuries of globalisation.

FRANK HEIDEMANN is professor for social and cultural anthropology at the Ludwig-Maximilians University Munich. Fields of interest are visual anthropology, social atmosphere and affect. His ethnographic research in the up-country of Sri Lanka, the Tamil plains in South India, the Nilgiri Hills and on the Andaman Islands includes themes on migration, politics, religion and rituals. At present he plans further fieldwork on Minicoy and the northern Maldive Islands. 


\section{Literature}

Barbosa, Duarte. 1515. The Isles of Malido, quoted from Vilgon (1991-1999), vol. 7: 11-13.

Bartholomeusz, O. 1885. Minicoy and Its People. London: Smith and Ebbs, quoted from Vilgon (1991-1999), vol. 3: 133-87.

Basevi, R. E. 1872. Account of the Island of Minicoy, The Journal of the Royal Geographical Society of London 42: 368-372.

Beckmann, J. 1809. Literatur der älteren Reisebeschreibungen. Nachrichten von ihren Verfassern, von ihrem Inhalte, von ihren Ausgaben und Übersetzungen, nebst eingestreuten Anmerkungen über mancherley gelehrte Gegenstände. Göttingen: Johann Friedrich Römer.

Bourdieu, P. 1990. The Logic of Practice. Stanford: Stanford University Press.

Cohn, B. S. 1987. An Anthropologist among Historians and Other Essays. Delhi: Oxford University Press.

Csordas, T. J. 2011. Cultural Phenomenology - Embodiment: Agency, Sexual Difference and Illness, in: Mascia-Lees, F. E., A Companion to the Anthropology of the Body and Embodiment. West Sussex: UK, Blackwell, 137-156.

Dirks, N. B. 2001. Castes of Mind. Colonialism and the Making of Modern India. Princeton and Oxford: Princeton University Press.

Ellis, W.H.R. 1924. A short Account of the Laccadive Islands and Minicoy. Madras, Government Press.

Fabian, J. 1983. Time and the Other. How Anthropology makes its Objects. New York: Columbia University Press.

Festetics de Tolna, R. 1904. Vers l'Ecueil de Minicoy, quoted from Vilgon (1991-1999), vol. 4: 153-93.

Forbes, A. D. W. 1978. Studies in Indian Ocean Islam: Caste and matriliny in the Laccadive Islands, Religion 8(1): 15-39.

- 1979. Sources towards a history of the Laccadive Islands, Journal of South Asian Studies 2(1-2): $130-150$.

Griffith, J. C. 1943. Inspecting officer. Minicoy Island, quoted from Vilgon (1991-1999), vol. 5: 241-57.

Kattner, E. 1996. The Social structure of Maliku (Minicoy), International Institute of Asian Studies (IIAS) Newsletter 10: 19-20, see also http://www.maldivesroyalfamily.com/minicoy_kattner.shtml.

- 2003. Maliku/Minicoy, a caravanserai in the midst of an ocean?, at: www.ioche.de (accessed 10 May 2016).

- 2007. Bodu valu - big ponds: Traditional water management and its socio-cosmic implication in Minicoy/Maliku, an Indian Ocean island, in: Ohlig, Christoph (ed.), Antike Zisternen. Siegburg: DWhG: 145-72.

- 2010. Seven men, six women: Names and the socio-cosmic order of Maliku (Minicoy Island), in: Berger, P., R. Hardenberg, E. Kattner, and M. Prager (eds.) The Anthropology of Values. Delhi: Pearson, 162-179.

Knoll, E.-M. 2018. The Maldives as an Indian Ocean crossroads. Oxford Research Encyclopedia of Asian History, at: oxfordre.com/asianhistory (accessed 10 December 2018). 
Kulikov, L. 2014. Traces of castes and other social strata in the Maldives: A case study of social stratification in a diachronic perspective (ethnographic, historic, and linguistic evidence, Zeitschrift für Ethnologie 139(2): 199-214.

Kurup, K. K. N. 1970. Ali Rajas of Cannanore, English East India Company and Lakkadive Islands, Proceedings of the Indian History Congress 32(2): 44-53.

Leydon, J. C. 1805. Journal of Doctor John Casper Leydon's Travels on the Brigg 'LOUISA VALLI' ... 1804-1805, quoted from Vilgon (1991-1999), vol. 3: 59-69.

Logan, W. 1889. The Island of Women, quoted from Vilgon (1991-1999), vol. 2: 99-151.

Malinowski, B. 1922. Argonauts of the Western Pacific. London: Routledge and Kegan Paul.

Maloney, C. 1980. People of the Maldive Islands. Bombay: Orient Longman.

Misra, K. P. and A. K. Tiwari. 1981. Life and society in Lakshadweep, Journal of the Indian Anthropological Society 16(3): 231-246.

Mohamed, N. 2008. Essays on Early Maldives. Male: National Centre for Linguistics and Historical Research.

Ptak, R. 1987. The Maldive and Laccadive Islands (liu-shan) in Ming Records, Journal of the American Oriental Society 107(4): 675-694.

Pyrard of Laval, F. 1611 (2010). The Voyage of Francois Pyrard of Laval to the East Indies, the Maldives, the Moluccas and Brazil, edited by Albert Gray and H.C.P, Bell. London: The Hakluyt Society 1888; reprinted by Ashgate 2010.

Romero-Frias, X. 2003. The Maldive Islanders. A Study of the Popular Culture of an Ancient Kingdom. Barcelona: Nova Ethnographia Indica.

- (n.d.). Muraidugandur Ali Manikfan: The man who loves nature from Minicoy, at: Maledivesroyalfamily.com (accessed 10 December 2018).

Schnepel, B. 2018. Introduction, in: Schnepel, B. and E. A. Alpers (eds.), Connectivity in Motion. Island Hubs in the Indian Ocean World. Cham: Palgrave, 3-32.

Schnepel, B. and E. A. Alpers (eds.). 2018. Connectivity in Motion. Island Hubs in the Indian Ocean World. Cham: Palgrave.

Severin, T. 1982. The Sindbad Voyage. London: Hutchinson.

Thomas, E. G. 1858. Report on the Management during Fusli 1268 of the five Laccadive Islands, quoted from Vilgon (1991-1999), vol. 7: 81-103.

Vilgon, L. 1991-1999. Maldive Odd History, vols. 1-9. Stockholm, published by the editor. Copies distributed to Libraries in London, Stockholm, and Male'.

Villiers, J. 1992. The Portuguese in the Maldive Islands, in: Earle, I. T. F. and S. Parkinson (eds.), Studies in the Portuguese Discoveries. Warminster: Aris and Phillips, 17-34.

Wolf, E. R. 2010 (1982). Europe and the People without History. Berkeley: University of California Press. 